\title{
Part Three, Introduction: On the Possibility of Entreating the Kingdom
}

\author{
Gabriella Caponigro
}

On reaching the threshold of Part Three of The Star, the reader might be tempted to think that the path of reflection undertaken so far might well be concluded, with Redemption, as expounded at the end of Part Two. But the redemptive space, formally considered within the horizon of revelation, does not substitute the final goal. The real world neither attains to the fullness of meaning nor does it contain the ultimate truth, so that the path experienced in it cannot but account for a dimension essentially incomplete.

If, on one hand, the cognitive dynamics of Parts One and Two are expressed by the figure of the Star by superimposing the two triangles ${ }^{221}$, on the other, the figure that comes across to us alludes to a supreme and ultimate truth, to a final port of call that forever remains beyond this world and which, as such, stays programmatically unfulfilled and postponed to futurity. However, the sense of such incompleteness needs to be understood, properly, as a "need for time"222 or rather as a "need of eternity". In other words, the figure of the Star still has to find its fulfilment and reveal itself in its truth, that is in its eternity.

${ }^{221}$ That of the elements God-Man-World (Part One) and that of the relational movements Creation-Revelation-Redemption (Part Two).

${ }^{222}$ Cf. Das neue Denken, GS III, 151.

How to cite this book chapter:

Caponigro, G. 2021. Part Three, Introduction: On the Possibility of Entreating the Kingdom. In: Brasser, M., Bojanić, P. and Ciglia, F. P. (eds.) The Star for Beginners: Introductions to the Magnum Opus of Franz Rosenzweig. Pp. 133-144. London: Ubiquity Press. DOI: https://doi.org/10.5334/bco.k. License: CC-BY 
Certainly, the real cosmos does maintain in itself the tension towards this hyper-cosmos, an intentionality directed to the ultimate consummation. Divine love poured upon man and the world demands substantiation in that eschatological dimension which Rosenzweig defines as "the eternal hyper-cosmos of the truth". For the philosopher, truth is not what is true but what longs to be confirmed as the truth ${ }^{223}$. It demands the sacrifice of life, the ethical, political and religious commitment of all generations; it longs to be anticipated in time. It is, therefore, understandable why in this part of the Star the function of the organon is taken on by the liturgy, being the system of visible signs typical of collective religious life that have the power to anticipate eternal reality.

Moreover, the truth longs to be beseeched, implored. For Rosenzweig the problem of truth is, evidently, the problem of desiring truth. What is at stake is redemption but, ever more so, the desire for redemption. Hence, the entire Introduction is dedicated to prayer ${ }^{224}$. That is the essential notion in the great shift from "the always-renewed-cosmos" to "the eternal-hyper-cosmos". It denotes a new temporality between the redeemer and the redeemed, just as it happens under forms of religious life, and indicates a new configuration of being, beyond-knowledge (erkennen) and beyond-experience (erleben) ${ }^{225}$.

Prayer implores the Kingdom of God, a reality to come which comprises the fulfilment of redemption. While redemption is already part of the real world as much as it is of creation and revelation, the Kingdom of God is present in

${ }^{223}$ Cf. GS III, 158. On the pragmatism of the truth, see our paper: G. Caponigro, Phenomenology of religious pragmatism. Truth and testimony in Franz Rosenzweig, in: "Archivio di filosofia/Archive of philosophy», LXXXIII, 2015, n.3, pp. 85-95.

${ }^{224}$ See also Part Two of The Star, which contains a number of significant reflections on prayer. It is defined as the greatest gift that is given unto man in revelation; however, a gift that comes across only as a possibility, as a "being able to pray", which must seek its fulfilment in the prayer for the coming of the Kingdom. See: GS II, 205-206, 260-261. For a comprehensive elaboration on the relationship between prayer and temporality, cf. Bernhard Casper, Über das Gebet. Betrachtungen zu Franz Rosenzweig im Hinblick auf Emmanuel Levinas, in: Philosophisch Theologische Grenzfragen. Festschrift für Richard Schaeffler, Essen 1986, 35-43; Das Gebet stiftet die menschliche Weltordnung. Zum Verständnis der Erlösung im Werk Franz Rosenzweigs, in: Gotthard Fuchs and Hermann Henrix (eds.), Zeitgewinn. Messianisches Denken nach Franz Rosenzweig, Frankfurt 1987, 127-150; Das Ereignis des Betens. Grundlinien einer Hermeneutik des religiösen Geschehens, Freiburg i.B., 1998.

${ }^{225}$ Cf. titles of the introductions to the three parts of The Star: Über die Möglichkeit das All zu erkennen, Über die Möglichkeit das Wunder zu erleben, Über die Möglichkeit das Reich zu erbeten (GS II, 3, 103, 295). 
the history of the world only - as Rosenzweig clarifies - as a growing reality ${ }^{226}$. This is a temporality completely different from that which can be intentionally calculated, a temporality that has no relation whatsoever with time ${ }^{227}$. Such growing reality is rather characterized by an intrinsic and unavoidable temporal disproportion between the messianic action of man, called to act and to sacrifice his own life for the coming of the kingdom, and the growth of the latter. The disproportion between man and world may only be removed with the advent of the Kingdom, when God, man and world become a unity ${ }^{228}$. However, the guarantee of the "becoming unity" lies in man's action. The cosmos becomes a redeemed hyper-cosmos awaiting man's action to become one with God's action.

The temporality on which human action is founded consists of distinct efforts to love one's fellow man, where every movement towards exteriority is always a new beginning ${ }^{229}$, as such inadequate in creating a continuous sequence and shaping a history. The world, however, has a history that develops independently of man, according to a continuous progression. This temporal disproportion explains why it is impossible for man to grasp any progress in the history of redemption and, as an immediate consequence, grasp any telos. The redemptive space brings about a true and proper "eschatological drama", an eschatology that never takes on the form of a teleology. In consequence, man's action is marked by its non-coincidence with respect to the worldly order and it cannot but proceed casually. The attainment of redemption, however, depends on the above coincidence. How then to reconcile, within the categories of the "new thinking", man's being in time with the worldly horizon and with God's being eternal and one?

The unknowability of the telos drives man to the fullness of being. Since man cannot predict the scheme of history, nothing remains unto man except to trustingly await, without any constriction, the fulfilment of God's work, which, in turn, needs man's free action to become true (bewähren). The concept of Bewährung thus turns into the cornerstone of the entire Part Three of The Star.

The non-teleological form of this "eschatological drama" underpins the absolute freedom and the space of human action. What kind of action can be considered effective, capable of activating the redemption process? In Rosenzweig's view, the knowledge must abandon the will in order to be able to transform itself

${ }^{226}$ Cf. GS II, 250-251.

227 "The tempo of this growth is not fixed, nay, more exactly: the growth has no relationship at all to time» (GS II, 250/ SH, 224). For an in-depth analysis on the special comprehension of temporality in Rosenzweig's thought, cf. F.P. Ciglia, Nel labirinto del tempo. Storia ed escatologia nel confronto fra Rosenzweig e Agostino, in: R. Panattoni, G. Sciolla (ed.), «Teologia Politica», 2, 2006, 144-185.

${ }^{228}$ Cf. GS II, 288.

${ }^{229}$ Cf. GS II, 239-240. 
into desire, which is essential to the coming of the Kingdom at the end of time. The redemptive action is the prayer, capable of reconciliating the temporality of man and the one of the world, and to project desires and intentions far in the future. Despite his cognitive defect and the limited horizon that surrounds him, man can resort to the prayer, the «utopian modality» ${ }^{230}$ of his action.

However, this projection of desires opens up a problematic horizon. As Stéphane Mosès asserts ${ }^{231}$, prayer projects us undoubtedly beyond our immediate horizon, but then, if it aims too far and demands the unattainable, it misses its appointment with the most attainable desire-the redemption. The latter does not let itself be taken arbitrarily at any moment in time, nor to be reduced to a simple actualization of desires. Redemption does not allow itself to be "ravished" by overbearing prayer, that demands the unattainable, instead of awaiting with trust and imploring that "ever possible" that makes up the very statute of redemption.

Therefore, now we may better understand why, in the caption to the Introduction, we find the motto In tyrannos! Beside the mottoes found in Parts One (In philosophos!) and Two (In theologos!), In tyrannos! bears testimony to the main preoccupation that animates Part Three and all of The Star: the risk of a relapse into subjectivism, in the infinite desire to embrace the fullness of history, to constitute oneself overlord of the heavens and of the last things. Prayer is certainly an itinerary directed to the last things but in an incomplete and non-teleological way. It is the possibility to put oneself at stake in the eschata, but the impossibility to avail of it.

The unknowability of the telos and of the rhythm that guides history establishes the free space of human action, but also the unavoidable possibility of missing the mark, of being led into temptation. One may miss the target because one is tempted. The idea of temptation emerges right from the Introduction. This is an essential category that explains the major peril inherent in man's action, that is man's will to replace God in the redemptive process. Hence, Rosenzweig writes: «Temptation will be as fundamental for the passage to Part Three as miracle for Part Two» ${ }^{232}$. Only before God the Redeemer does one have the unlimited liberty to decide and to tempt God; a liberty that would not be possible were it not God first to tempt man, that is to hide Himself, so that the individual may have the possibility to freely choose whether to believe and confide in Him or to replace Him with himself.

As emphasized above, redemption opens unto man a problematic horizon, not only with regard to what has just been said about its utopian peculiarity but also because it is not God's direct work. It is rather an indirect work of

${ }^{230}$ Cf. Stéphane Mosès, Système et Révélation. La philosophie de Franz Rosenzweig, Paris, 1982, 158ff.

231 Ibid., 161.

${ }^{232}$ Letter to Margrit Rosenstock-Huessy, dated 13 October 1918, in: GB, 169, our translation. 
His, which takes place wherever the freedom poured forth in the act of love joins the mutable life of the world in a relationship. Only in this relationship does the real possibility of tempting God occur and it is prayer that institutes such a rapport.

Without the enlightenment of prayer love's action would be blind, it would not see the history of the world, neither a telos, nor the world itself. It would only be directed to those who happen to be the fellow man from time to time. Prayer thus enlightens the world that, otherwise, love alone would not be able to see.

However, in instituting the human order of the world, the prayer runs the risk to overcome the act of love and tyrannically move towards the last things. Because it is impatient, the tyrannical prayer is ineffective: «True, the man enlightened in prayer would like to adduce the kingdom of heaven forcibly, before its appointed time. But the kingdom of heaven will not be coerced: it grows. And thus, the magic power of the individual suppliant falls into the void if it strays beyond the nearest» ${ }^{233}$. There is a desirable time-a time of grace for praying. Not only does the tyrannical prayer miss its appointment with that time-coming too early_but also with the fellow being. The act of love, which does not know telos nor history, becomes, in the tyrant's prayer, an act aimed at an unattainable utopia. Whereas the desirable time is one in which human will accords perfectly with the objective state of the things of the world. Hence, Rosenzweig affirms, there is no wrongful content of prayer, but only a wrong moment.

The time in which redemption grows is that of the life of the world, whose rhythm and laws it is not given to man to know. However, despite this unknowability, the possibility is conceded to man to see his prayers answered, if such prayer takes place precisely in the acceptable time of grace.

This time demands a further effort on the part of man, a trust $\mathrm{t}^{234}$ that drives actions and intentions towards achievable objectives. The experience of the future must always be able to find support in the natural time of the world, because the redemption is precisely the most realistic desire.

But if man does not have the realistic wisdom to understand his creatural limits, his prayer cannot but be tyrannical. The fanatic, the sectarian, the mystic, all

${ }^{233}$ GS II, 302; SH 271.

234 The notion of Vertrauen takes on a fundamental role in various passages of The Star. It is not only what animates faith in revelation, in the man who awaits the Kingdom (cf. the introduction to Part Two), but also it is the essential attitude that unites Jews and Christians in their common task to bear witness to the truth. The proof whereof is that the word recurs in the crucial portions that conclude The Star (GS II, 472). For an in-depth analysis of the argument, see: Irene Kajon, Il concetto di Vertrauen nella Stella della Redenzione, in: Il futuro del nuovo pensiero. In dialogo con Franz Rosenzweig, «Teoria», 28, 2008. 1, 159-173. 
of heaven's tyrants, end up exhausting the act of love, thus delaying the coming of the Kingdom which they impatiently wanted to accelerate.

Apart from the visionary, Rosenzweig also identifies another equally barren attitude to the future, that of the sinner, that is of the man who does not trust God's redemption and wastes the time of grace in praying for somethingone's own being-which he already possesses right from the creation. His is an egoistic prayer, he prays for his Own self, so that the fellow man eternally remains a "he", an object amongst the many in the world of creation. Thus, by breaking the bond with the world and the fellow man, the sinner denies the work of redemption which, by contrast, consists in orienting oneself towards a "he" as if he were one other "I". Hence, Rosenzweig's definition: "For what is redemption other than that the I learn to say Thou to the He?» ${ }^{235}$. Thus, the sinner who remains within the limits of "his Own self", anchored to what he already possesses, that is to his past, misses the encounter with the fellow man thereby delaying, again, the coming of the Kingdom.

On the other hand, effective prayer is one that keeps abreast of love, raised at the opportune time. But, asks Rosenzweig, how and when is this prayer raised?

At this point, Rosenzweig surprisingly introduces the figure of Goethe ${ }^{236}$, «the man of life», "the pure son of this earth»-as he describes the poet-the fulfilment of paganism, the incarnation of earthly and natural wisdom. Effective prayer is the one recited by Goethe, who has managed to fully reconcile his intentionality with the mutable life of the world: "Labour of my hands that I / finish, grant, oh Fortune high!» ${ }^{237}$. It is the prayer of a solitary individual, addressing neither the future of the Kingdom nor his own self, but his personal destiny. The notion of "destiny" is a decisive one. It designates the fulfilment, in the overall course of life, of the true and proper essence of man; this is what makes man one and indivisible in his singularity, a microcosm, which, at the same time, unites him with the world, roots him and makes him grow in it. Man is in the world in so far as he has a destiny. This intimate bond that ties the part to the whole, human life to the entire life of the world, is precisely what destiny is. And it is this intimate bond, corresponding to a segment, to an hour, that which has to be implored in prayer. "And, that being so, this prayer is always fulfilled. Even as it is prayed, it insinuates itself into the face of the world; it never misses its mark, is never too late nor too early [...] it occurs in the

235 GS II, 305; SH, 274.

236 The Star is full of references, some of which implicit, to Goethe's work. Most of those references are contained in the Introduction hereby examined. To Rosenzweig, Goethe's life represented a synthesis of classical harmony, the only possible reconciliation of the duality between the objective and the subjective, between world and self, which constituted the great theoretical problem of the initial period of his speculative work. Cf. notes dated 11.1.06, 19.2.06, 16.03.06, 27.4.06, 6.5.06, 4.9.06, in: GS I.1.

237 GS II, 306; SH, 274. 
personal hour [...] Accordingly, it is ever in the desirable time» ${ }^{238}$. To Rosenzweig, all of this signifies nothing but entering upon what has always existed in the world - in creation - and thereby come into redemption, since the latter consists in the union of the object of the revelation - man - with that of the creation - world - which is to say in the coming together of a plan and a history.

The prominent reference to Goethe throws a new light on the reality of paganism, as a reality that opens up the possibility of man's reconciliation with the world's time, that is the very object of redemption. Rosenzweig writes: "Goethe is really at the same time the great pagan and the great Christian» ${ }^{239}$. If the statement about Goethe's paganism may easily be understood-he represents the unbelief of the creaturely being-the one regarding Christianity is less comprehensible. Even Goethe describes himself as the only remaining Christian. Such a claim may be understood if what is meant by Christian is someone who longs to live like Christ binding himself to the destiny of the world. Goethe is one who, with his concrete life, has brought to fulfilment the spirit of Christianity-it being the exaltation and sanctification of creation.

At this juncture, in order to account for Goethe's uniqueness, Rosenzweig develops the history of Christianity as one of paganism. Die Nachfolge Christi is a decisive passage in the Introduction, since it sheds light on Rosenzweig's conception of the secularisation of Christianity. Taking a leaf out of Schelling's Philosophie der Offenbarung ${ }^{240}$, Rosenzweig subdivides the history of Christianity into three fundamental stages, each corresponding to an apostle and a theological virtue, each reflecting a certain relation of the Church with the life of the world.

The Church of Peter, risen out of the ruins of the Roman Empire, was the one that turned to the whole world as a missionary, transcending the borders of the nations. It built churches throughout the world, and organised itself as a visible body. The individual, and with him the Church itself, finds himself immediately inserted, by way of love, in the life of the world. However, what was tied to the destiny of the world was only "the destiny of his act, not, however, the destiny of his thought» ${ }^{241}$. Therefore, although the Petrine Church was able to

${ }^{238}$ GS II, 308; SH, 277.

239 GS II, 315; SH, 283.

${ }^{240}$ Friedrich Schelling, Philosophie der Offenbarung, 1854. On the importance of Shelling's philosophy in Rosenzweig's thought, see: Xavier Tilliette, Rosenzweig et Schelling, in: "Archivio di filosofia», LIII, 1985, n. 2-3, 141152; Wolfdietrich Schmied-Kowarzic, Vom Totalexperiment des Glaubens. Kritisches zur positiven Philosophie Schellings und Rosenzweig, in: Id. (ed.), Der Philosoph Franz Rosenzweig (1886-1929), Internationaler Kongress Kassel 1986, Vol. 2, Freiburg/München 1988, 771-799; Robert Gibbs, The Limits of Thought: Rosenzweig, Schelling and Cohen, in: «Zeitschrift für Forschung», 43 (1989), 614-640.

${ }^{241}$ GS II, 311; SH, 280. 
convert the external visible paganism, it could do nothing about the internal paganism, which was remembered and survived in a Christianised world. The power of love, which always acts towards a corporeal exterior, could not fight such a paganism. A different instrument was needed in order to divert the eyes from the world «which acted within the soul itself and upon the soul» ${ }^{242}$, freeing it of its paganism.

Faith was this instrument that acted with power in the Pauline centuries, which, in Rosenzweig's reconstruction, correspond to the centuries of the Protestant Reform. The Church of Paul certainly converted the soul, but dearly paid for such an internalisation of the faith with the loss of the unity of the visible body. Having become the invisible Church of a religion reduced exclusively to the ambit of interiority and subjectivity, it soon showed its weakness: if the Petrine Church had been too bound up with the body, the Pauline Church was too focused on the soul to the extent that, at the end of the Pauline centuries, it was from such a weakness that German Idealism with its idea of a self-producing spirit, unmindful of the body, drew its energies. Faith, in regaining the soul, had lost the body and the world. Protestant theology and Idealist philosophy marked the triumph of subjectivity, but, conversely, they paved the way for secularism.

However, Rosenzweig asserts, man is an indivisible microcosm. His essence lies neither in the body nor in the soul, but becomes so fulfilling itself in the world through his destiny, which is at once body and soul. Since this destiny may be prayed for, this is where such dualism is transcended, a new time is inaugurated: that of the consummation of Christianity. Hence, the pagan prayer, that of a non-religious but creaturely faith, can become the prayer of all Christian peoples, who, like Goethe in his singularity, would be able to access the destiny of the world and grow with it. Growth and fulfilment ought to be able to coincide in life.

Thus, the new future Church will not be one of the exterior or interiorised pagan, but that of the living pagan, who sacrifices his own life in the trusting expectation of fulfilment. Hope will be the greatest virtue, which comprises in itself love and faith, and leads it back neither to the external nor to the internal, but, on an axis of temporality, towards the future. As in the Gritlianum dialogue, from their separation body and soul join together in the cry of hope: «O dass du den Himmel zerrissest und führest hernieder!» ${ }^{243}$. This is the age of the living pagan, of Johannine completion, which, being the fulfilment of the preceding figures, does not take on any specific form and does not become visible as a third Church. And since such a Church is not built, in Rosenzweig's view, it can only grow. Underlying here is a veiled critique of Rosenstock's vision of

${ }^{242}$ GS II, 312; SH, 281.

${ }^{243}$ GB, 826-831. Cf. GS II, 206; SH, 191. For an in-depth analysis of the text, see: Francesco Paolo Ciglia (ed.), Il grido, Morcelliana, Brescia 2003. 
Christianity as Ecclesia triumphans ${ }^{244}$. The Kingdom of Heaven must not be identified with the reign of the Church, nor with any other visible institution. Instead, it is an invisible community that is to bring to fulfilment the time, the community of a religion of humanity.

It is at this point that Rosenzweig introduces the Jewish people as the constituent element of this new Christian age. However, it is not an emancipated Judaism that enters political reality as a visible character, participating in the history of peoples and nations, but the Judaism of the Holy Covenant, which becomes, beside and within Christianity itself, the element of the Johannine civilisation. Rosenzweig writes: "Accordingly, in this incipient fulfilment of the ages it is rather the Jew, accepted into the Christian world, who must convert the pagan within the Christian. For hope [...] lives as a matter of blood-inheritance only in Jewish blood» ${ }^{245}$.

The father of this Johannine Church is none other than Goethe, who, in his prayer to destiny, has created a time that is alive, a current in which could grow the vitality of the creaturely life of the man. But his prayer, which must certainly be given credit for having brought temporality back to life, is not a prayer for the advent of the Kingdom, rather it interrupts its growth. It is its unavoidable precondition, as it leads man back to the singularity of the creaturely life, but not a sufficient condition, since such pure temporality needs to access eternity. More appropriately, an accelerative power must be added to life's pure temporality in order to anticipate the future in Today, to transform eternity into an "Infinite Now". Such prayer which accelerates the coming of the Kingdom is the one pronounced by the believer: completion and not abolition of the unbeliever's prayer. Such prayer demands much more than the fulfilment of destiny, it desires eternity here and now.

This is perhaps one of the key passages to understand the heart of the problem of redemption. Rosenzweig introduces the notion of "hour" as metaphor of eternity. It represents the cyclic recurrence of the identical, the projection of the immutable in perceived time. Certainly, not the hour as a temporal, transient, fluid projection, but as an abiding moment, as a nunc stans, like «a circle returning in upon itself $»^{246}$. In order to redeem himself from the transient, man transforms into "hour" the natural rhythm of the times of the sun and the moon. Thus, year, month and day become "hours" in human life. Through such a human institution, man gives time an immutability that becomes the projection of eternity.

The week, in particular, a purely human time, marked by the alternation of work and rest is, as such, a "true hour". It represents the point in which human

${ }^{244}$ Cf. the second book (GS II, 390-392) and the third book of Part Three (GS II, 445-447). Cf. also the correspondence between Rosenzweig and Rosenstock in particular the letters dated 7.11.16, 30.11.16, in GS I.1.

245 GS II, 317; SH, 285.

${ }^{246}$ GS II, 322; SH, 290. 
and sacred time converge by intertwining. This is even more evident on the day of rest, which is the day consecrated not only to the contemplation of the work done by man in the preceding six days, but also to the blessing of God's work, that is of creation. The week articulates and regulates the cultural service of the earth, but, in its infinite repetition, it is also the earthly representation of the eternal. This passage takes place through the fundamental mediation of the liturgical rite. Natural time transformed, through cultural repetition of the earth, into human-social time, is in turn transformed through liturgical repetition into time suited to the reception of eternity. Thus, Rosenzweig writes, the week is «the kernel of the cult», «temporal abodes into which the eternal is invited $»^{247}$. In other words, sacred time stands on and is understood on the basis of profane time.

Returning to prayer: what does it really comprise, and where does the power of this prayer lie that makes it capable of extending such an appealing invitation to the eternal as to be indeclinable? Precisely in liturgical time, that is in the time that belongs to everyone.

The believer's prayer is the prayer of the entire community and what is highlighted to all its members is not a personal destiny but the shared reality: the end of all things, that which is the farthest, the Kingdom. Since the self-same reality to come is highlighted in the experience of an entire community, the individual may now really raise himself above his own horizon of finiteness. The believer's prayer is the consummation of the unbeliever's prayer: it is indeed necessary for life to come alive with unbelieving prayer in order to be able to receive the gift of the eternal in time. Therefore, Goethe's "May I fulfil the work of $m y$ hands" can no longer suffice, but "May thou fulfil the work of our hands". Hence, it becomes clear why the prayer to the Kingdom marks the threshold point between the manifest cosmos and the hyper-cosmos. It mediates between revelation and redemption and its concrete form in the religious community, the liturgy, with its power to anticipate, cannot but be the organon of Part Three of The Star.

The figure with the two superimposed triangles, may now shine as a star and become fully visible. This bright figure will not be revealed by way of language, as in Part Two, but it will do without words in order to become pure liturgical gesture, the gesture of arms raised to the heavens, "which is eloquent without the lips having to move» ${ }^{248}$.

In the liturgical gesture the pagan's prayer fuses with that of the believer: the intention turned to one's own action in history now becomes one and the same with the intention turned to the eternity of the Kingdom. Here lies the heart of Rosenzweig's vision of history: the relation between human action and the last things, which is the core of Part Three of The Star. The history of salvation takes place each time anew amongst free intentions oriented to the Kingdom

247 GS II, 324; SH, 292.

248 GS II, 328; SH, 295. 
and the consummation of time. If it were not so, human action would only be able either to remain ineffective, bringing about acceleration or delay in the advent of the Kingdom, or, on the contrary, be effective but interrupt its growth in history.

Men himself becomes the request, the cry addressed to the eternal Kingdom, because what is at stake is the relation between love and the world, human action and the last things, the finite possession of time and the eternal reality. Redemption is thus possible only in the yearning that it be fulfilled, recognising its ever being beyond anything containable within knowledge or experience. Man may only act oriented by the desire to become-one with God and the world, according to a modality that he can never fully embrace.

All of Part Three of The Star may thus be understood only in the light of that motto, In tyrannos!: against all totalitarianisms of heavens, all presumption to embrace all of history and the entire truth, against radical subjectivism that overcomes creatural limits ${ }^{249}$.

Unbelief and faith become one: «God's truth wants to be entreated with both hands» ${ }^{250}$, with the hands of the believer and the unbeliever. Truth demands that the incessant and eternal quest for realisation join the quest oriented by the hope of the Kingdom towards a common goal; the intentionality must fuse with the historical experience of a calling to the eternal. The unbeliever's hand has to rise together with that of the believer, with the hand - we might add - of Judaism and Christianity, as will be seen in the following books of The Star.

${ }^{249}$ Expanding this issue to collective tyranny, the motto "in tyrannos!" acquires significance within Rosenzweig's polemic against the tyrannical power of the State and Hegel's universal history (see Book One, Part Three of the Star). For further elaborations of Rosenzweig's view on politics, see: Stephane Mosès, Politique et réligion chez Franz Rosenzweig, in: Jean Halpérin (ed.), Politique et réligion, Paris 1981, 283-311; Gérard Bensussan, Etat et éternité chez Franz Rosenzweig, in: Arno Münster (ed.), La penseé de Franz Rosenzweig, Paris 1994, 137-148; Id., Instant éthique et raison politique, in: Wolfdietrich Schmied-Kowarzik (ed.), Franz Rosenzweigs "neues Denken «, Internationaler Kongress Kassel 2004, Vol. 1, Freiburg/München 1988, 459-469; Marc Crépon, Politiques de Rosenzweig, in: Ibid., 516-537; Guy Petitdemange, Hegel et Rosenzweig, la différence se faisant, in: Olivier Mongin (ed.), Franz Rosenzweig, "Les Cahiers de la nuit surveillée" 1 (1982), 157-170; Jörg Kohr, "Gott selbst muss das letzte Wort sprechen». Religion und Politik im Denken Franz Rosenzweigs, Freiburg/München, 2008. For further elaborations on "tyranny" as it appears in different ways along the various stage of Rosenzweig's thought, see: Irene Kajon, La critica della tirannia in Franz Rosenzweig, "Archivio di Filosofia" 59, 1991, n. 1-3, 219241. See also our work: G. Caponigro, Unde Malum? Libertà e tirannia in Franz Rosenzweig, preface by Bernhard Casper, Ets, Pisa 2015.

250 GS II, 330; SH, 297. 


\section{Further readings}

Bernhard Casper, Das Gebet stiftet die menschliche Weltordnung. Zum Verständnis der Erlösung im Werk Franz Rosenzweigs, in: Gotthard Fuchs and Hermann Henrix (eds.), Zeitgewinn. Messianisches Denken nach Franz Rosenzweig, Frankfurt 1987, 127-150.

Sax, B., (2011), Das geflügelte Wort: Franz Rosenzweig as Post-Goethekenner, in: Naharaim 5 (2011) 115-149, [https://www.degruyter.com/journal/key /NAHA/5/1-2/html]

Stéphane Mosès, Système et Révélation. La philosophie de Franz Rosenzweig, Paris 1982. 